\title{
EXTENT OF VIABILITY OF UTILIZING INTERNET SHOPS AS AN ALTERNATIVE LABORATORY IN INTERNET AND COMPUTING FUNDAMENTALS: BASIS FOR A PROPOSED ACADEME-INDUSTRY LINKAGE PROGRAM
}

\author{
Kurt B. Catolico
}

Glan School of Arts and Trades

\begin{abstract}
This study attempted to determine the extent of viability of utilizing internet shops as an alternative laboratory in Internet and Computing Fundamentals taking into consideration the marketing; technical; management and organization; financial and socio-economic aspects of a feasibility study. Respondents of the study were internet shop owners in Barangay Poblacion, Glan, Sarangani Province whose shops were in close proximity to Glan School of Arts and Trades.

The study found out that the extent of utilizing internet shops as an alternative laboratory for grade nine Internet and Computing Fundamentals students of Glan School of Arts and Trades is much viable. Hence, an academe-industry linkage program is proposed. This program will serve as a guide in the implementation of the venture which is an innovative approach to address the gap between grade nine students who have access to the school computer laboratory from those who do not have.
\end{abstract}

Keywords: Extent of Viability of Utilizing Internet Shops, Internet Shops as Alternative Laboratory, Internet and Computing Fundamentals, Academe-Industry Linkage Program

\section{Introduction}

The government has been spending much to provide learners with meaningful learning approaches in teaching computer skills. Fisher (2014) emphasized that technology continues to move on a pace and is used increasingly to support and enhance teaching and learning. Several studies have already proven that learning could be significantly improved with the use of computers.

But considering the number of students and the limited learning and financial resources of the Glan School of Arts and Trades (GSAT), three out of eight grade nine class sections for school year 2014-2015 have been unable to gain access to the school computer laboratory due to conflicting schedules. Although the school had been granted a set of 50 computers, still it is not enough to cater the need for hands-on activities of 1,402 grade seven to grade nine Internet and Computing Fundamentals (ICF) students of GSAT for school year 2014-2015. Adding to the problem is that these computers have been experiencing system failures attributable to its weak infrastructure. Tinio (2002) as cited by Jayoma (2013) mentioned the existence of barriers that hinder the use of computers in the teaching and learning process in her study that covers public high schools throughout the country.

Bingimlas (2009a) echoed the same difficulties in his study that was conducted outside of our country. The biggest obstacle identified was the lack of enough computers attributable to the burgeoning student population. Further hindrances included were lack of funds for operations and maintenance. Problems attributed to weak infrastructure and scheduling enough computer and internet time for different classes were also noted.

It is in this view that the teacher-researcher conducted this study to look at the extent of viability of utilizing internet shops noticeably mushrooming in close proximity to schools nowadays as an alternative laboratory for 
Kurt B. Catolico/Extent of Viability of Utilizing Internet Shops as an Alternative Laboratory in Internet and Computing Fundamentals: Basis for a Proposed Academe-Industry Linkage Program

hands-on activities of grade nine students in their Internet and Computing Fundamentals subject. This venture is expected to bridge the gap between students who have access to the school computer laboratory and those who do not have.

\section{Statement of the Problem}

This study aimed to determine the extent of viability of utilizing internet shops as an alternative laboratory in Internet and Computing Fundamentals.

More specifically, it sought to answer the following questions:

1. What is the extent of viability of utilizing internet shops as an alternative laboratory for grade nine GSAT ICF students when analyzed according to the following aspects:t

- Marketing;

- Technical;

- Management and Organization;

- Financial;

- Socio-economic?

2. What academe-industry linkage program can be proposed based on the finding of the study?

\section{Methodology}

\section{Research Design}

The nature of the study called for the extensive use of the feasibility study which according Fonollera (2009) is an evaluation tool used to determine the practicality of a certain idea. It is a tool that systematically explores whether a given idea will work and whether it should be pursued further for implementation. The study also used survey method of research.

\section{Research Locale}

This study was conducted at Barangay Poblacion, Glan, Sarangani Province which boasts of its pristine shorelines dotted with strips of powdery white-sand beach resorts facing the Celebes Sea which is among the Philippines' best beaches. Glan is among the earliest Christian towns in Mindanao testified by its century-old traditions and the colonial-era structures that stand until today.

\section{Research Respondents}

The respondents of this study were the identified internet shop owners currently operating their businesses within Barangay Poblacion, Municipality of Glan, Province of Sarangani and in close proximity to the Glan School of Arts and Trades. Table 1 shows the distribution of respondents. 


\section{Instrumentation}

A survey questionnaire was prepared as research instrument in gathering the data. It is the best instrument that can supply the necessary information to complete this study. The said instrument was used to measure the extent of viability of this venture. It was structured wherein the respondents gave their responses by rating the extent of viability of the indicators as guided by a five-point scale. The indicators were grouped according to the aspects of a feasibility study which are marketing; technical; organization and management; financial and socioeconomic. The scale assigned five as the highest rating which can be interpreted as very much viable. This is followed by four which can be interpreted as much viable; then three as viable; two as less viable; and one which is the lowest as not viable.

\section{Statistical Tools}

Weighted mean was used as a statistical tool to treat the research data.

\section{Results and Concluding Discussions}

This study determined the extent of viability of utilizing internet shops as an alternative laboratory for grade nine Glan School of Arts and Trades students in their Internet and Computing Fundamentals subject. This was identified using a survey questionnaire that considered the marketing; technical; management and organization; financial; and socio-economic aspects of a feasibility study; and measured using weighted mean.

The marketing survey focused on how internet shops can accommodate three class sections of grade nine GSAT ICF students who do not have access to the school computer laboratory which is approximately 50 students per class. The marketing survey obtained a mean score of 3.80 which is the lowest among the five aspects of a feasibility study being surveyed and can be interpreted as much viable. The survey shows that internet shops have limited capacity. Two out of five respondent internet shops can accommodate for as much as $60 \%$ of the students, the rest can accommodate only 10 to 30 percent. In terms of the days and hours that the students can be accommodated by these shops, it shows that during school days and school hours, internet shops are not jampacked. Internet shops are operating at its peak after school hours, between 11:00 am to 1:00 pm and from 5:00 pm to 7:00 pm. Table 2 shows the result of the marketing survey.

The technical survey focused on the existence of computer hardware and software required to carry out the purpose of utilizing internet shops as alternative laboratory for grade nine GSAT ICF students. Moreover, it focused on the safety of the students which is of paramount concern. The technical survey result shows a high mean score which is 4.67 that can be interpreted as very much viable. This means that internet shops are technically ready to admit students who need their services. Table 2 shows the technical survey result of the study.

The management and organization survey focused on the acceptability and permissibility of the internet shop to enter into a Memorandum of Agreement with the school for the shop to be used as an alternative laboratory for grade nine GSAT ICF students. This survey also dealt with how the shop could manage to prioritize students from walk-in customers during the agreed laboratory time and to provide additional equipment if necessary. The management and organization survey obtained a mean score of 4.67 which is similar to that of the technical aspect and can be interpreted as very much viable. This means that the shop is eager to help the school in enhancing the computer skills of the students who have no access to the school computer laboratory. Table 2 shows the management and organization survey result.

The financial survey focused on the computer usage rate the internet shop can offer to the students. Moreover, it tackled on other discount deal on top of the discounted rate that the shop can offer. The survey obtained a mean 
score of 3.93 which can be interpreted as much viable. The survey shows that internet shops are willing to lower their usage rate from Php12.00 to Php10.00. Further, the shops are also willing to offer additional discount deal such as a free one hour laboratory time for every 10 hours of laboratory time used. Most of the internet shops affirmed that they would earn additional income when they would forge partnership with the school in using their shops as an alternative laboratory in ICF. Table 2 shows the financial survey result.

The socio-economic survey focused on the contribution of the internet shop to the economy; to the school community and their acceptability of the venture which they can adopt as their corporate social responsibility. The survey obtained a mean score of 3.93 which is the same as that of the financial aspect and can be interpreted as much viable. It shows that internet shops are willing to forge partnership with the school and are considering this linkage as part of their corporate social responsibility. Table 2 shows the result of the socio-economic survey.

The overall result of the survey attained a grand mean of 4.20. This result leads to an understanding that the extent of viability of utilizing internet shops as alternative laboratory for Glan School of Arts and Trades grade nine students in Internet and Computing Fundamentals is much viable. Table 2 shows the result of the study which is conducted to five internet shops that are in close proximity to GSAT.

\section{Marketing Aspect}

Ferrell (2013) described marketing as a process of creating, distributing, promoting, and pricing goods, services, and ideas to facilitate satisfying exchange relationships with customers and develop and maintain favourable relationships with stakeholders in a dynamic environment. This aspect discusses the process as mentioned by Ferrell that would satisfy the need of the customers - the students who have no access to the school computer laboratory. These students need equitable access to computer resources to develop their computer skills. Specifically, this aspect discusses the product this venture is expected to offer; the target market for this venture; the estimated market share; the market demand and supply; the pricing method; and the location of these internet shops.

Product. Ferrell (2013) defined product as a good, service or idea. This venture is evaluating the practicality of the idea that internet shops can be utilized as an alternative venue for hands-on activities of grade nine GSAT students in their ICF subject. With this venture, internet shops are expected to offer services to students by letting them use computers during the agreed laboratory time at a discounted rate for their laboratory work in ICF and attending to technical problems that might arise during the aforementioned laboratory activity. The services that would be rendered to these student customers are geared towards bridging of the gap between GSAT grade nine students who have access to the school computer laboratory from those who do not have.

Target Market. Ferrell (2013) explained target market as a group of customers on which marketing efforts are focused. The target market then for this venture is the grade nine GSAT ICF students who do not have access to the school computer laboratory. Out of eight class sections for grade nine GSAT students for school year 20142015, three sections have been unable to gain access to the school computer laboratory due to conflicting schedules. These three sections were composed of 149 students. It is approximately 50 students per class. Table 3 shows the projection of grade nine students who would be availing of the service of internet shops being an alternative laboratory for their hands-on activities in ICF for the next five school years. In order to come up with this projection, data for this school year and the last two school years were used. In school year 2012-2013, there were 154 students who were not able to avail of the services of the school computer laboratory while for school year 2013-2014, the number decreased a little bit to 152. The decreasing number of students is attributed to the decreasing enrolment due to the establishment of integrated schools as observed by the school records officer. The projection was computed based on the above stated data using the average rate of decrease. To get the rate of decrease for school years 2012-2013 and 2013-2014, 154 was subtracted to 152 then the difference of 
two was divided by 154 and then multiplied by 100 . The rate of decrease is $1.30 \%$. To get the rate of decrease for school years 2013-2014 and 2014-2015, 152 was subtracted to 149 then the difference of three was divided by 152 and then multiplied by 100 . The rate of decrease resulted to $1.97 \%$. Now, to get the average rate of decrease, $1.30 \%$ was added to $1.97 \%$ which summed up to $3.27 \%$. The sum was then divided by two to get the average rate of decrease which is $1.64 \%$. Using the average rate of decrease, it is estimated that the number of target students would decrease by two students per school year until school year 2019-2020.

Estimated Market Share. The market share refers to the portion of the market that can be catered by the venture since they cannot be catered by the school computer laboratory. To compute for the market share, the enrolled grade nine GSAT students for school year 2014-2015 had to be determined. School records showed 395 enrolled grade nine students of GSAT for school year 2014-2015. Grade nine students who have no access to the school computer laboratory have already been identified earlier. They were 149 students. To get the number of students who have access to the school computer laboratory, the total number of grade nine students which is 395 was subtracted with 149 . This resulted to a difference of 246 . With these data at hand, the market share could then be computed. The estimated market share of this venture was computed by dividing 149 by 395 then multiplied by 100. This resulted to $38 \%$. In computing the percentage of grade nine students catered by the school computer laboratory, 246 was divided by 395 multiplied by 100 . This resulted to $62 \%$. Figure 1 shows the pie graph of estimated market share of the venture.

Market Demand and Supply. The market demand refers to the number of students of Glan School of Arts and Trades who need the services of a partner internet shop as an alternative laboratory for their hands-on activities in their Internet and Computing Fundamentals subject. These are grade nine students who have no access to the school computer laboratory. The demand had been identified earlier to be 149 students for school year 20142015. Based on the projected number of students who have no access to the school computer laboratory as shown in Table 3 on the previous page, the demand is decreasing. For the next five school years, the demand is estimated to reach only to 139 students. This is approximately 46 students in a class. The cause of the decreasing demand had been identified earlier as being brought about by the establishment of integrated schools. This was based on the observation and investigation of GSAT records officer. She explained further that those students from other barangays especially those from far flung areas had opted to enrol in integrated schools in their respective communities to save on transportation costs. Supply on the other hand refers to how the identified need would be met. Supply then would be focusing on the accommodation capacity internet shops can offer for the market which was identified earlier as the students with no access to the computer laboratory. The accommodation capacity of internet shops is limited as compared to the average number of students per class that reached 50 students for school year 2014-2015. The most that an internet shop could cater is only $60 \%$ of students in a class. This is based on the survey conducted which showed that there were two shops that have 30 computer units available for use of students. The survey further attested that internet shops could cater students only during off peak hours which is school hours. It starts from 7:00 until 11:00 in the morning and from 1:00 to 5:00 in the afternoon. The internet shops are jam-packed at 11:00 in the morning to 1:00 in the afternoon. Peak hours resume from 5:00 in the afternoon until 7:00 in the evening. This scenario implies that students are the primary market of these internet shops.

Pricing Method. Internet shops identified as respondents of this study uniformly charge their customers Php12.00 per hour of computer usage. This means that the pricing method used is the competition-based pricing strategy specifically the going-rate pricing. According to Mutya (2014), this approach to pricing charges the same price with that of major competitors.

Location. These internet shops are strategically located near schools which have a constant flow of potential customers who are students. Figure 2 shows the strategic location of the said internet shops. 


\section{Technical Aspect}

Technical Process. In this section, the whole process of the venture will be discussed. First, a feasibility study should be conducted to know if the venture of utilizing internet shops as an alternative laboratory in ICF is viable or not. This step would facilitate in identifying which shop should be chosen to partner with. Then, preoperating activities should be done. Pre-operating activities include the setting up of the linkage program committee. This should then be followed by the drafting of the Memorandum of Agreement. According to Department of Education Western Australia (2010), a Memorandum of Agreement is a written agreement that helps establish the ground rules for any partnership activities being ventured into. In this venture, it is the linkage program committee that would spearhead the drafting of the Memorandum of Agreement. A series of conferences and consultations should be made before finalizing the Memorandum of Agreement. After that, the signing of the Memorandum of Agreement would follow. Signing of the Memorandum of Agreement signifies the launching of the proposed linkage program. Then, identifying class sections and students who have no access to the school computer laboratory should be conducted. Next should be the holding of an orientation program for parents to understand the venture and gain their all out support. This should be followed by the scheduling of laboratory time in the partner internet shop. Profiling of computer skills of students would come next. This is done to determine the level of knowledge a student already possess in using the computer. This would be used as basis in pairing students during the conduct of laboratory work at the partner internet shop to maximize the limited accommodation capacity. Then, orienting students on laboratory activities in the partner internet shop should follow. Lastly, coordinating with the partner internet shop in the preparation for the start of laboratory activities should be done. After the pre-operating activities, operating activity would follow. This includes conducting laboratory activities in the partner internet shop. Post-operating activity would be the last process. This includes conducting post-conferences to evaluate and monitor the implementation of the venture. Figure 3 shows the service flow chart.

Laboratory Activity Needs. For the skills development of the identified grade nine GSAT ICF students who have no access to the school computer laboratory, the venture would be needing facilities; machinery and equipment; furniture and fixtures; and utilities. Facilities include the internet shop room and a comfort room. Machinery and equipment include computers that are networked and connected to the internet; and cooling devices such as airconditioner and electric fans. Furniture and fixtures needed are tables and chairs. Utilities include water and electricity. Table 4 shows the particulars, quantities and specifications of the needs previously mentioned.

Laboratory Schedule. The total laboratory hours needed is 22 which would start on July and end on February of the school year totalling to eight months of operation. Laboratory schedule in the partner internet shop is tentatively scheduled as shown in Table 5 .

Safety and Health Requirements. Safety and health requirements are needed in obtaining the necessary annual permit to operate from government agencies and offices such as the Bureau of Internal Revenue, Bureau of Fire Protection, Department of Health, Municipal Planning and Development Office, Office of the Barangay Captain and Office of the Municipal Mayor. These requirements ensure the health, safety, peace, comfort, convenience and the general welfare of the students who would be availing of the services of the partner internet shop. Based on the survey conducted, all internet shops have fire extinguishers, fire exits and electrical safety devices installed such as circuit breakers and magnetic switches. Other considerations such as good ventilation, suitable lighting, enough working space, cleanliness and sanitation of the area and the imposition of the solid waste management are evident in the shops. 


\section{Management and Organization Aspect}

Organizational Form and Structure. The venture is a partnership between the school and the internet shop which can best accommodate the number of grade nine students who have no access to the school computer laboratory. Department of Education Western Australia (2010) stated that one of the reasons a school enters into partnerships is to provide an opportunity to share skills, effort, cost, and resources for mutual benefit. The school and the internet shop are two separate entities that would work closely and collaboratively in providing students with equitable access to computer resources. With this, the school is able to solve its computer-related problem while the shop earns additional income. Furthermore, this venture would use a simple structure of management. Robbins and Judge (2011) stated that the simple structure is not elaborate because it has a low degree of departmentalization and authority is centralized in a single person. The venture would be headed by the school administrator who is the person in authority. All persons in the organizational chart are already existing and currently functioning in their respective area and capacity. For the purpose of this venture, a partnership would be established thus, the need to appoint a linkage program coordinator arises to help the school administrator in managing the implementation of the venture. Figure 4 shows the organizational structure of the venture.

Job Specification and Description. For the effective operation of the program, a linkage program committee should be established. A linkage program coordinator then is needed. He or she should be chosen from among the faculty of the vocational department teaching Internet and Computing Fundamentals. The succeeding paragraph discusses the qualifications of the proposed internet shop linkage program committee coordinator.

The linkage program committee coordinator must: (a) be an ICF Teacher; (b) have at least 5 years experience as an ICF teacher; (c) be a Computer Hardware Servicing NC-II passer; (d) be good in oral and written communication skills.

The subsequent paragraphs discuss the duties and responsibilities of each person in the implementation of the proposed linkage program.

The Vocational School Administrator should: (a) initiate the establishment of the linkage program committee; (b) appoint a linkage program coordinator; (c) work closely with the linkage program coordinator in line with the planning, implementation, evaluation and monitoring of the program; (d) attend conferences called for the purpose.

The Vocational Department Head should: (a) assist the school administrator in the establishment of the linkage program committee and the appointment of the linkage program coordinator; (b) work closely with the school administrator and the linkage program coordinator in line with the planning, implementation, evaluation and monitoring of the program; (c) attend conferences called for the purpose.

The Linkage Program Committee Coordinator should: (a) spearhead the drafting of the Memorandum of Agreement and other documents required; (b) seek to sustain the partnership between the school and the partner internet shop; (c) consolidate the needed reports; (d) schedule conferences needed in the conduct of the linkage program; (e) preside over planning, monitoring, and evaluation conferences; (f) work closely with the school administrator, the department head, the internet shop owner, the ICF teacher and the shop assistant in line with the planning, implementation, evaluation, and monitoring of the program.

The Internet Shop Owner should: (a) work closely with the linkage program coordinator, the ICF teacher and the shop assistant in line with the planning, implementation, evaluation and monitoring of the program; (b) attend conferences called for the purpose. 
The ICF Teacher should: (a) assist the linkage program coordinator in preparing the needed documents; (b) prepare the necessary reports; (c) orient students on the guidelines for the safe and orderly conduct of laboratory activities; (d) supervises laboratory activities in the partner internet shops; (e) work closely with the linkage program coordinator, the internet shop owner and the shop assistant in line with the planning, implementation, evaluation and monitoring of the program; (f) attend conferences called for the purpose.

The Shop Assistant should: (a) ensure the readiness of the shop prior to a scheduled laboratory activity; (b) work with the ICF teacher during laboratory activities whenever technical assistance is needed; (c) work closely with the linkage program coordinator, the internet shop owner and the ICF teacher in line with the planning, implementation, evaluation and monitoring of the program; (d) attend conferences called for the purpose.

Pre-Operating Activities. These are activities prior to the conduct of laboratory work in the partner internet shop. These include: Conduct of a feasibility study; establishment of the linkage program committee; drafting and eventually the signing of the Memorandum of Agreement after a series of consultations and conferences with the school's stakeholders; identification of class sections and students who have no access to the school computer laboratory; profiling of computer skills of the students; holding of an orientation program for parents; scheduling of laboratory time; orienting students on laboratory activities in the partner internet shop; and coordinating with the partner internet shop in preparation for the start of laboratory activities. Figure 5 shows a Gantt chart which illustrates the schedule of activities prior to the implementation of the venture.

Documentary Requirements. This venture requires the drafting of a memorandum of agreement between the school and the partner internet shop that will serve as a guide in the implementation of the venture. Other needed documents include a linkage program. This program reflects the description and rationale of the venture. It also reflects the objectives, the methodology matrix, the laboratory schedule and the means of evaluation and verification.

\section{Financial Aspect}

Financial Assumptions. Revenue from the venture would be realized through the delivery of services of the partner internet shop. Accounting for the revenue is essential in the preparation of the income statement. According to Brigham (2014), an income statement is a report that summarizes the revenues, expenses and profits during a reporting period of a particular business or venture. Assumptions that would serve as a guide in the preparation of the income statement are discussed in the succeeding paragraphs.

The income statement of the venture is to be prepared at the end of the school year. Service Income from the venture is to be projected for the next five years. Fanollera (2009) emphasized that projected financial statements such that of an income statement generally cover the first five years. It is assumed that the internet shop which can best accommodate the number of students would be used as basis in the computation of service income. It would not be computed based on the number of target students but rather on the full capacity of the partner internet shop. The annual service income that would be generated by this venture was derived from determining the accommodation capacity of the partner internet shop which in this case is 30 students per hour based on the maximum number of computer available for the use of students which is 30 computer units. This was then multiplied to the regular rate per hour which is Php12.00. The product then was multiplied to the total number of laboratory hours in one school year which is 22 hours. The result was multiplied again to the number of class sections who would be benefiting from the venture which is three sections to finally arrive at the annual service income of the venture.

Since income is to be projected for the next five years, the regular computer usage rate for the first year of operation should be subjected to increase using the average inflation rate for the last five years. This is done to cover also the rising expenses due to inflation. According to Harrison (2010) inflation is an increase in the price 
of goods or services that is not offset by an increase in quality. To compute for the average inflation rate, inflation rates for the last five years should be determined. The year 2010 obtained an inflation rate of 3.8\%. For the year 2011 it was $4.7 \%$. It was $3.2 \%$ for the year 2012. It plummeted to $2.9 \%$ in the year 2013 . The year 2014 reaped a rise to $4.2 \%$. These figures were summed up and then divided by five to get the average inflation rate of $3.76 \%$. With this, the regular computer usage rate of Php12.00 for the first year was subjected to increase by $3.76 \%$ in the following year up to the fifth year. Table 6 shows the projected service income.

The estimated expenses directly attributable to the operation of the venture were determined through interviews with internet shop owners. Expenses included were salaries and wages of the shop assistant; depreciation of facilities, equipment, furniture and fixtures; rent of the shop room; internet connection fee; utilities which consist of electricity and water; permit and licenses; and repairs and maintenance of the computer units. Depreciation expense was computed using the straight-line method. Harrison (2010) elaborated that in the straight line-method, an equal amount of depreciation is assigned to each year or period of asset use. Harrison added that in order to come up with depreciation expense using the aforementioned method, estimated useful life of the asset is determined. Estimated useful life is the length of service expected from using the asset. In this case, the estimated useful life of computers was assumed to be five years. The useful lives of other laboratory needs such as other machines and equipment; and furniture and fixture were assumed to be 10 years. Depreciation was computed by determining the total amount of depreciable assets. The amount was then divided by the useful lives of the determined depreciable assets to get the annual depreciation expense. From the annual depreciation expense, the hourly depreciation expense could then be computed. This was then multiplied to the total number of laboratory hours in a school year then multiplied again by the total number of class sections who would be benefitting from the venture to arrive at the total depreciation expense of the venture. Other expenses were also computed by getting the hourly expense multiplied to the total number of laboratory hours in a school year then multiplied again by the total number of class sections who would be benefitting from the venture. These expenses were assumed to increase using the previously computed average inflation rate for the last five years which is $3.76 \%$. Appended supporting schedules that show the amount of each of the specified expenses are presented on page 72,73 and 74 .

Valencia and Roxas (2013) stated that a registration for VAT business of a taxpayer becomes compulsory when the annual gross sales or receipts of the business exceed 1,919,500.00 a year. Since internet shops were not able to reach that requirement, they were not qualified to be considered a VAT business, hence, they were generally subjected to three percent other percentage tax on gross sales or receipts. Table 6 shows the projected income statement to be generated by the partner internet shop through the venture.

\section{Socio-Economic Aspect}

This section discusses the contribution of the venture to the government; its effect to the students; its contribution to the school; and the corporate social responsibility.

Contribution to the Government. This venture has a significant contribution to the economy. With an additional income, the partner internet shop could pay more taxes thus generating more income to the government in funding government projects such as infrastructures and social services that improve living conditions of the people in the community.

Effect to the Students. According to Geselbracht (2000) as cited by Bingimlas (2009) that this venture when pushed through would result to the provision of quality access to computer resources for grade nine GSAT ICF students. Geselbracht added that with this, interest of students in learning could greatly improve which would then result to improved learning outcomes. 
Contribution to the School. This venture would help the school in bridging the gap between students who have access to the school computer laboratory from those who do not have.

Corporate Social Responsibility. This venture can be considered as the corporate social responsibility of the partner internet shop. The partner internet shop is engaged in an activity that is very beneficial to the educational community. The discounted rate and additional discount deal that the partner internet shop is willing to offer would be a great contribution to the community as a whole because it advocates the aim of the community to become a one sharing and caring community.

Fanollera (2009) stated that the result of a feasibility study serves as a basis for deciding to pursue its implementation or not. With the findings of this study, the proposed idea of utilizing internet shops as an alternative laboratory in ICF worked and should be pursued.

Based on the findings of the study, an academe-industry linkage program is proposed. Profeta (2003) as cited by Hagos and Dejarme (2008) asserted that personal growth and development are best achieved by an educational method that combines classroom learning with periodic intervals of planned and supervised practical experience outside of the academe. Below is the proposed academe-industry linkage program.

\section{References}

Bingimlas, K. A. (2009). Barriers to the successful integration of ICT in teaching and learning: a review of the literature. Eurasia Journal of Mathematics, Science and Technology Education.

Brigham, E., et. al. (2014). Core concepts of financial management. Singapore: Cengage Learners Asia.

Department of Education Western Australia (2010). A guide to establishing partnership arrangements between schools and registered training providers. Retrieved on January 22, 2015 from http://www.det.wa.edu.au/ curriculumsupport/vetis

Fanollera, D. (2009). Module 1: Feasibility study, project proposal and business plan. Zamboanga:Western Mindanao State University Printing Press.

Ferrell, O. C., et. al. (2013). Marketing. Singapore: Cengage Learning Asia.

Hagos, L. \& Dejarme E. (2008). Enhancing curriculum in Philippines school in response to global community challenges. Our Lady of Fatima University. Retrieved on September 10, 2014 from http://ro.ecu.edu.au/cgi/view content.cgi?article=1020\&context=ceducom.

Harrison, W. T. (2010). Financial accounting: International financial reporting standards. Singapore: Pearson Education South Asia.

Mutya, R. F. (2014). Elements of marketing. Quezon City: National Book Store.

Robbins, S. P. \& Judge, T. A. (2011). Organizational behavior. Singapore: Pearson Education South Asia.

Valencia, E. G. and Roxas, G. F. (2013). Transfer and business taxation: Principles and laws with accounting applications. Baguio City: Valencia Educational Supply.

\section{Appendices}

Table 1 Distribution of Respondents

\begin{tabular}{|c|c|c|}
\hline Respondents & $\mathrm{f}$ & $\%$ \\
\hline Greenzone Internet Cafe & 1 & $20 \%$ \\
\hline Redzone Internet Cafe & 1 & $20 \%$ \\
\hline Rage Quit Internet Cafe & 1 & $20 \%$ \\
\hline $\begin{array}{l}\text { Ghaga Taping Portrait and } \\
\text { Internet Cafe }\end{array}$ & 1 & $20 \%$ \\
\hline Hotspot Internet Cafe & 1 & $20 \%$ \\
\hline $\begin{array}{ll}\text { Total } \\
\end{array}$ & 5 & $100 \%$ \\
\hline
\end{tabular}


Proceeding of the $3^{\text {rd }}$ International Conference on Education, Vol. 3, 2017, pp. 266-279

Table 2 Extent of Viability of Utilizing Internet Shops as an Alternative Laboratory in ICF

\begin{tabular}{lcc}
\hline \multicolumn{1}{c}{ Indicators } & Mean Score & Description \\
\hline 1. Marketing Aspect & 3.80 & Much Viable \\
\hline 2. Technical Aspect & 4.67 & Very Much Viable \\
\hline $\begin{array}{l}\text { 3. Management and } \\
\text { Organization Aspect }\end{array}$ & 4.67 & Very Much Viable \\
\hline $\begin{array}{l}\text { 4. Financial Aspect } \\
\text { 5. Socio-economic Aspect }\end{array}$ & 3.93 & Much Viable \\
\hline & 3.93 & Much Viable \\
\hline
\end{tabular}

Table 3 Projected Number of Grade Nine Students who have no Access to the School Computer Laboratory for the Next Five School Years

\begin{tabular}{lccccc}
\hline & $2015-2016$ & $2016-2017$ & $2017-2018$ & $2018-2019$ & $2019-2020$ \\
\hline $\begin{array}{l}\text { Projected Number of Students } \\
\begin{array}{l}\text { Projected Average Number of } \\
\text { Students per Class }\end{array}\end{array}$ & 147 & 145 & 143 & 141 & 139 \\
\hline
\end{tabular}

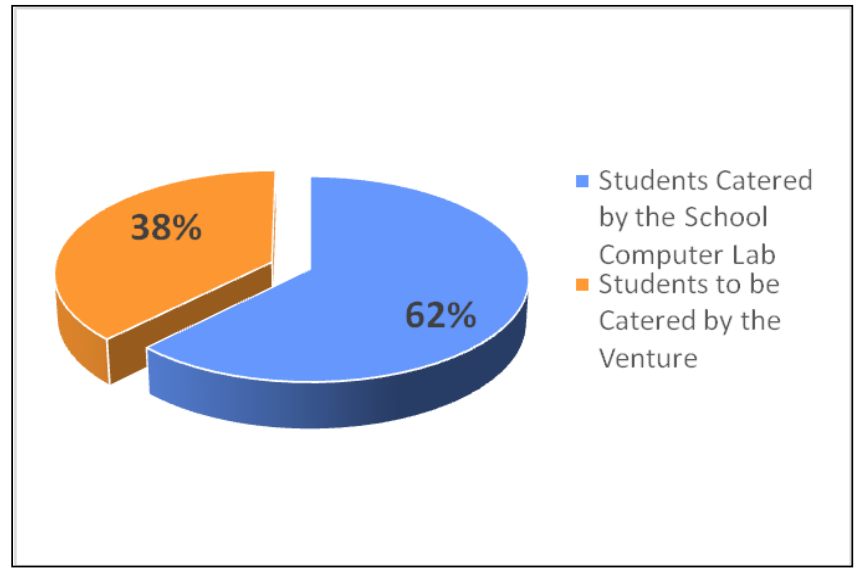

Figure 1. Estimated Market Share of the Venture

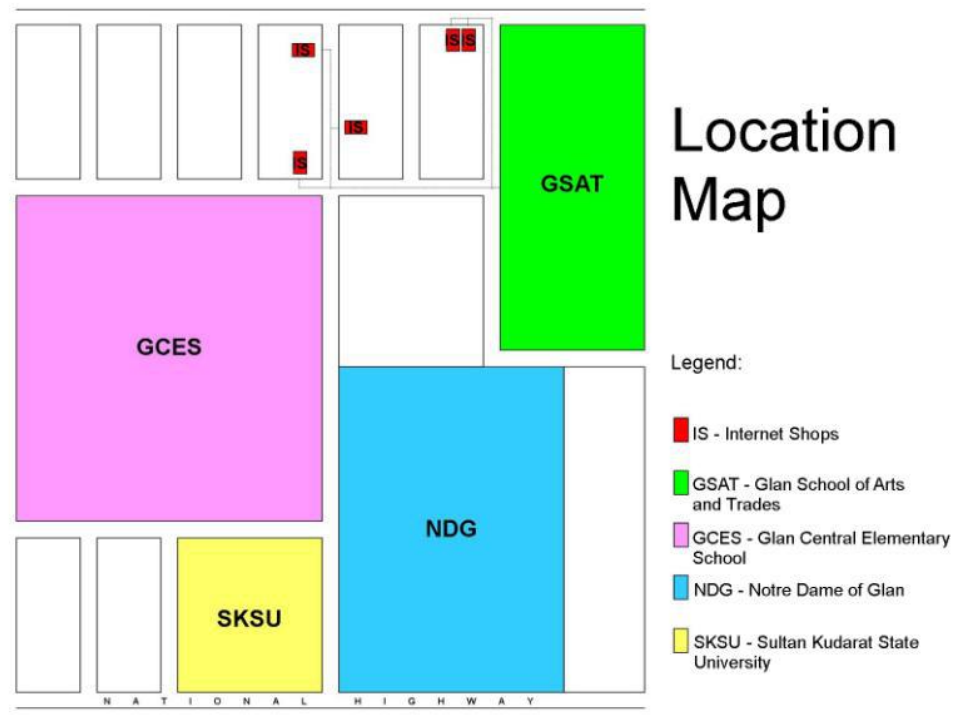

Figure 2. Location Map of Glan School of Arts and Trades and Internet Shops 
Kurt B. Catolico/Extent of Viability of Utilizing Internet Shops as an Alternative Laboratory in Internet and Computing Fundamentals: Basis for a Proposed Academe-Industry Linkage Program

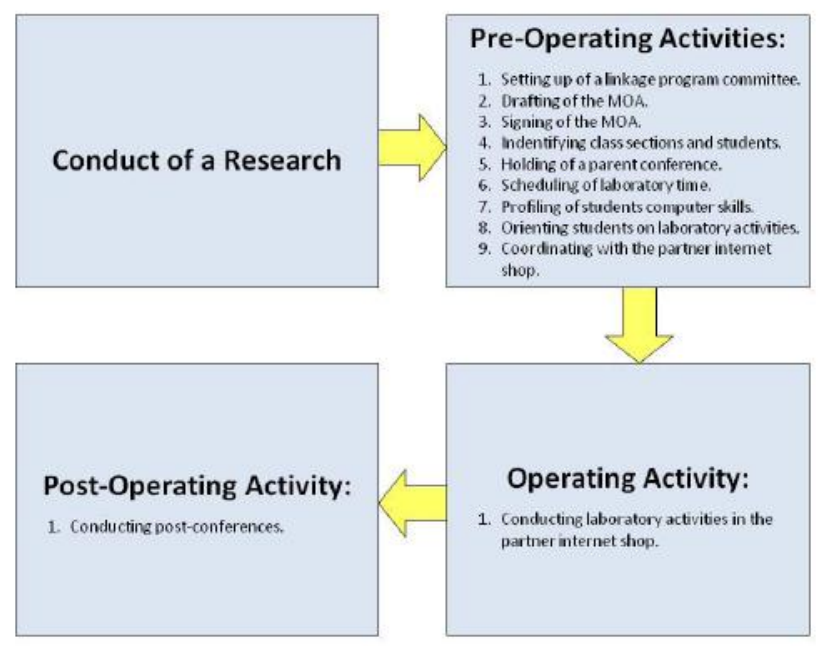

Figure 3. Service Flow Chart of the Venture

Table 4 Laboratory Activity Needs

\begin{tabular}{|c|c|c|}
\hline Particulars & Quantity & Specifications \\
\hline \multicolumn{3}{|l|}{ Facilities } \\
\hline Shop Room & 1 & Can accommodate 50 students. \\
\hline Comfort Room & 2 & Genderized \\
\hline \multicolumn{3}{|c|}{ Machineries and Equipment } \\
\hline Personal Computers & 30 & $\begin{array}{l}\text { Internet connected; networked; } \\
\text { with access to a printer; } \\
\text { with other peripherals such as } \\
\text { webcam, speaker or headphone, } \\
\text { microphone, back-up devices; } \\
\text { installed with MS Word, Excel, } \\
\text { PowerPoint and Internet } \\
\text { Explorer; } \\
\text { installed with a firewall and an } \\
\text { anti-virus software. }\end{array}$ \\
\hline Airconditioning Unit & 1 & Window type; 2.5 horse power. \\
\hline Electric Fan & 2 & Stand Fan \\
\hline \multicolumn{3}{|l|}{ Furniture and Fixtures } \\
\hline Long Tables & 6 & $\begin{array}{l}\text { With division and can cater } 5 \\
\text { computers per table. }\end{array}$ \\
\hline Table/Counter & 1 & $\begin{array}{l}\text { Designed for cashiering and for } \\
\text { the server. }\end{array}$ \\
\hline Chairs & 31 & Mono-block plastic chairs \\
\hline
\end{tabular}

Table 5Tentative Laboratory Schedule

\begin{tabular}{lcc}
\multicolumn{1}{c}{ Learning Outcome } & $\begin{array}{c}\text { No. of Lab } \\
\text { Hours }\end{array}$ & Time \\
\hline 1. Access the Web & 4 & $3^{\text {rd }}$ and $4^{\text {th }}$ week of July \\
\hline 2. Search the Web & 3 & $3^{\text {rd }}$ and $4^{\text {th }}$ week of August \\
\hline 3. Download Web Pages & 3 & $3^{\text {rd }}$ and $4^{\text {th }}$ week of September \\
\hline
\end{tabular}


Proceeding of the $3^{\text {rd }}$ International Conference on Education, Vol. 3, 2017, pp. 266-279

\begin{tabular}{|c|c|c|}
\hline 4. Send and Receive E-mail & 5 & $\begin{array}{c}3^{\text {rd }} \text { week of October } / 1^{\text {st }} \text { and } 2^{\text {nd }} \text { week of } \\
\text { November }\end{array}$ \\
\hline 5. Create PowerPoint Presentation & 7 & $\begin{array}{c}3^{\text {rd }} \text { and } 4^{\text {th }} \text { week of January } / 1^{\text {st }} \text { and } 2^{\text {nd }} \text { week of } \\
\text { February }\end{array}$ \\
\hline Total No. of Lab Hours & 22 & \\
\hline
\end{tabular}

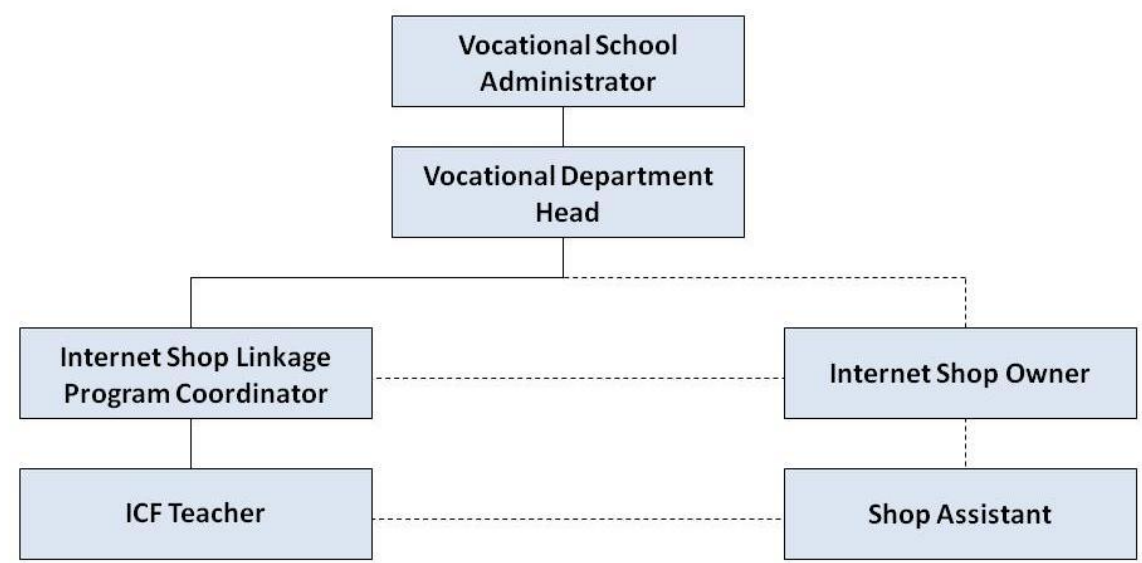

Figure 4. Organizational Chart of the Venture

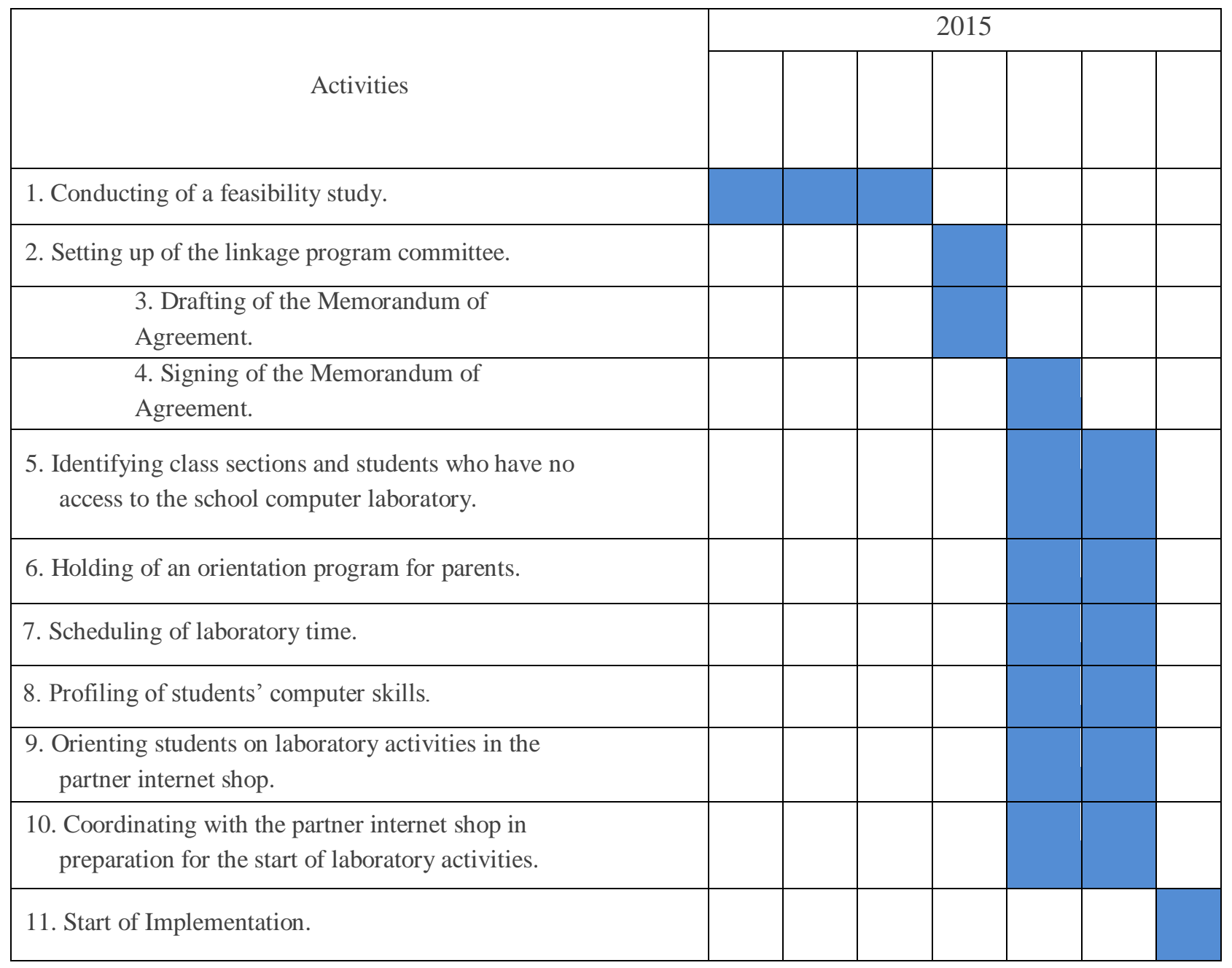


Kurt B. Catolico/Extent of Viability of Utilizing Internet Shops as an Alternative Laboratory in Internet and Computing Fundamentals: Basis for a Proposed Academe-Industry Linkage Program

Figure 5. Gantt Chart for Pre-Operating Activities

Table 6 Projected Income Statement for the Next Five Years

$$
\begin{aligned}
& \text { Partner Internet Shop } \\
& \text { Income Statement }
\end{aligned}
$$

(Income to be Generated through Partnership with GSAT)

For the School Year ended March 2016, 2017, 2018, 2019, 2020

$\begin{array}{llll}2016 & 2017 & 2018 & 2019\end{array}$

Service Income

$$
23,760.00
$$

$24,653.38$

$25,580.34$

$26,542.16$

$27,540.15$

\section{Expenses}

Salaries and

Wages

458.33

475.56

493.44

512.00

531.25

Depreciation

$$
1,397.45
$$

$1,449.99$

$1,504.51$

$1,561.08$

$1,619.78$

Rent

916.67

951.14

986.90

$1,024.01$

$1,062.51$

Internet

Connection

183.33

190.22

197.38

204.80

212.50

Utilities

504.17

523.13

542.80

563.21

584.38

Permit and

Licenses

71.70

74.40

77.19

80.10

83.11

Repairs and

Maintenance

Total Expense

Operating Income

Business Tax (3\% of

Gross Income)

114.58

118.89

123.36

128.00

132.81

\begin{tabular}{rrrrr}
\hline $3,646.23$ & $3,783.33$ & $3,925.58$ & $4,073.18$ & $4,226.33$ \\
\hline $20,113.77$ & $20,870.05$ & $21,654.76$ & $22,468.98$ & $23,313.81$ \\
712.80 & 739.60 & 767.41 & 796.26 & 826.20 \\
\hline
\end{tabular}

Net Income

$19,400.97$

$20,130.45$

$20,887.35$

$21,672.72$

$22,487.61$ 